\title{
THE DEVELOPMENT OF ANALYTICAL METHODS FOR THE ELEMENTAL DETERMINATION OF BIOTIC INDICATORS PRESENT IN AQUATIC ECOSYSTEMS
}

\author{
PETRA HERMAN ${ }^{a *}$, SÁNDOR HARANGI ${ }^{a}$, MILÁN FEHÉR ${ }^{b}$, \\ ISTVÁN FÁBIÁN ${ }^{a}$, EDINA BARANYAI ${ }^{a}$
}

\begin{abstract}
In our research we investigate the accumulation extent of the inorganic contaminants accessing the aquatic food chain, including zooplankton and fish species through model experiments. In this paper we discuss the preliminary experiments considering the measurement of iron and manganese accumulated in Artemia sp. after hatched and reared in metal contaminated model media. The goal is to develop the sample preparation and analytical methods required for the determination of metals adsorbed in the studied organisms. We proved that rinsing the zooplankton organisms three times with $2 \mathrm{~mL}$ per grams (wet weight Artemia) of rinsing solution prior to the sample preparation process decreased the possibility of analytical error. European Reference Material of fish tissue $\left(E M^{\circledR}-B B 422\right)$ was used to validate the applied sample preparation and atomic spectrometric methods. The average recovery value for the measured elements by open system digestion with conventional heating was $96 \%$ and $92 \%$ with microwave digestion. With MP-AES $99 \%$ and $92 \%$ were gained, respectively. According to our results no significant difference occurred between the digestion in open system with conventional heating and microwave assisted digestion as well as the cost effective microwave plasma atomic emission spectrometry (MPAES) proved to be appropriate for the routine quantitative analysis of adsorbed elements in zooplankton organisms and fish tissues.
\end{abstract}

Keywords: zooplankton, fish tissue, sample preparation, elemental analysis, atomic emission spectrometry

\footnotetext{
a Department of Inorganic and Analytical Chemistry, Agilent Atomic Spectroscopy Partner Laboratory, University of Debrecen, Debrecen H-4010, Hungary

${ }^{b}$ Faculty of the Agricultural and Food Sciences and Environmental Management, University of Debrecen, Debrecen H-4032, Hungary.

* Corresponding author: hpetra327@gmail.com
} 


\section{INTRODUCTION}

Considering their shape and their expansion, ecosystems can be quite diverse. All the trophic levels setting up the system have their own functions: animals are the consumers, plants are the producers, while microorganisms play an important role in decomposing organic matter. In case of aquatic ecosystems, zooplankton are the base of the food chain, serving resource for consumers on higher trophic levels (including fish). These organisms are able to effectively accumulate several inorganic nutrients and pollutants in their body without suffering significant damage. However, more advanced and more complex organisms consuming them can create much higher concentrations in their cells and tissues through bioaccumulation than it was in the initial environmental media [1-2].

In the aquatic systems elements occur in the form of organic and inorganic compounds. They can be grouped according to multiple criteria: based on their effect on living organisms there are essential and toxic elements, while considering their quantity we talk about macro or micro elements [3]. The elemental contaminants may enter surface water in different ways. Nowadays more and more attention is given to anthropogenic activities (industrial production, agricultural production, traffic) as well as communal waste, which all play significant role in increasing the elemental concentrations above the environmental threshold limits [4-5]. However, there are heavy metals that occur in a naturally high concentration (background value) in the earth's crust, thus contributing to their presence in the surface waters.

For the aquatic organisms, the right elemental dose of the surrounding medium is indispensable. The elements have important biological role in the body, so both their absence and presence above the permitted levels can lead to adverse health problems. Thus animals maintain a delicate balance in their body, properly coordinating the different parameters of ingestion, storage and excretion. The availability of the various elements is affected by many factors, including their different chemical form and concentration, and also their interaction with other elements [6].

Toxicity tests are used to investigate the effect of several chemicals and pollutants on organisms, comparing the sensitivity of the individual species. In aquatic toxicity studies bacteria, zooplankton and fish are examined most commonly [7-9]. These organisms represent different trophic levels in the food chain and indicate the quality of the surrounding water.

In our research group we investigate the accumulation of inorganic contaminants accessing the aquatic ecosystems. Zooplankton and fish species are used in these experiments as bio indicator organisms which are reared in contaminated model media. The accumulated concentrations of elements are measured from their tissues providing information about the 
extent of pollution. In present study we discuss the results of preliminary experiments considering the techniques applied for the sample preparation and elemental determination. The widely applied instrumental techniques for elemental analysis require the samples to be in solution. In case of environmental studies the correctly chosen sample preparation has a particular importance, since over $90 \%$ of the measurement errors arise from this step of the analytical process.

Emission methods of atomic spectroscopy uses different plasma based induction sources to produce the excited atoms required for the qualitative and quantitative analytical information. Inductively coupled plasma optical emission spectrometers (ICP-OES) use argon as plasma gas, which provides a high temperature emission source $(\sim 10000 \mathrm{~K})$. This can be an advantage in case of elements which require higher excitation energy, yet the continuous gas supply can increase the operating and measuring costs. The newly launched microwave plasma atomic emission spectrometer (MP$\mathrm{AES}$ ) works on a similar principle but the plasma requires nitrogen gas which is produced continuously by a generator. The microwave induced excitation source has a lower temperature $(\sim 5000 \mathrm{~K})$ compared to that of the ICP, thus while the method itself is quite cost effective, its sensitivity is overall lower.

The first aim of our study is to determine the need of rinsing the zooplankton organisms with ultrapure water after the enrichment period. The second aim is to find the analytical method suitable for the sample preparation and elemental analysis. In order to verify the required analytical steps fish tissue ERM ${ }^{\circledR}$-BB422 was applied that contains elements in certified values and has a matrix similar to that of the samples. In the method development process two different sample preparation techniques - digestion in open system with conventional heating and in a microwave assisted system were compared. The more expensive microwave assisted digestion utilizes microwave energy which enables the efficient and rapid heating of the samples, while the cost effective digestion in open system with conventional heating is a more time consuming technique [10]. In the elemental analytical step we further compared the performance of the well-known and widely applied ICP-OES method with MP-AES, regarding the digested ERM ${ }^{\circledR}-B B 422$ samples.

\section{RESULTS AND DISCUSSION}

\section{Rinsing of enriched zooplankton organisms}

After harvesting Artemia samples we rinsed them in ultrapure water prior to the further analysis to remove the remaining surface contamination. The three rounds of rinsing solutions were collected and analyzed for Fe and $\mathrm{Mn}$. 
Literature data is quite controversial: some suggest washing the organisms with distilled water [11] although it can cause the remove of the elements from the cells due to osmosis. Other papers mention seawater or tap water depending on the rearing media [12-14], however it can contaminate the samples; while not rinsing the zooplankton organisms at all can result in a positive measurement error. According to our results in the first round of rinsing the collected solutions enriched $\mathrm{Fe}$ and $\mathrm{Mn}$ in a relatively large concentration. Thus we concluded that this could not be a result of releasing the elements from Artemia due to osmosis rather from the Fe and Mn contaminated model water remained on the surface of the zooplankton organisms.

As we expected, the concentration of the elements used for the enrichment was gradually decreased in the rinsing liquids, as indicated in figure 1 and 2. The higher the original concentration was in the treatments the higher percentage decrease was observed in the rinsing solutions. The $\mathrm{Fe}$ and $\mathrm{Mn}$ concentration was reduced by an average of $45 \pm 6 \%$ in CC, $75 \pm 6 \%$ in $\mathrm{MC}$, $82 \pm 2 \%$ in $\mathrm{CM}$ and $80 \pm 1 \%$ in MM treatment in the last round of rinsing compared to the first.

According to our results, rinsing the organisms three times definitely proved to be necessary, since it causes smaller systematic measurement error. It is important to mention, that the rinsing should happen with a very small amount of water ( $2 \mathrm{ml}$ per $\mathrm{g}$ of wet weight Artemia) and short contact time.

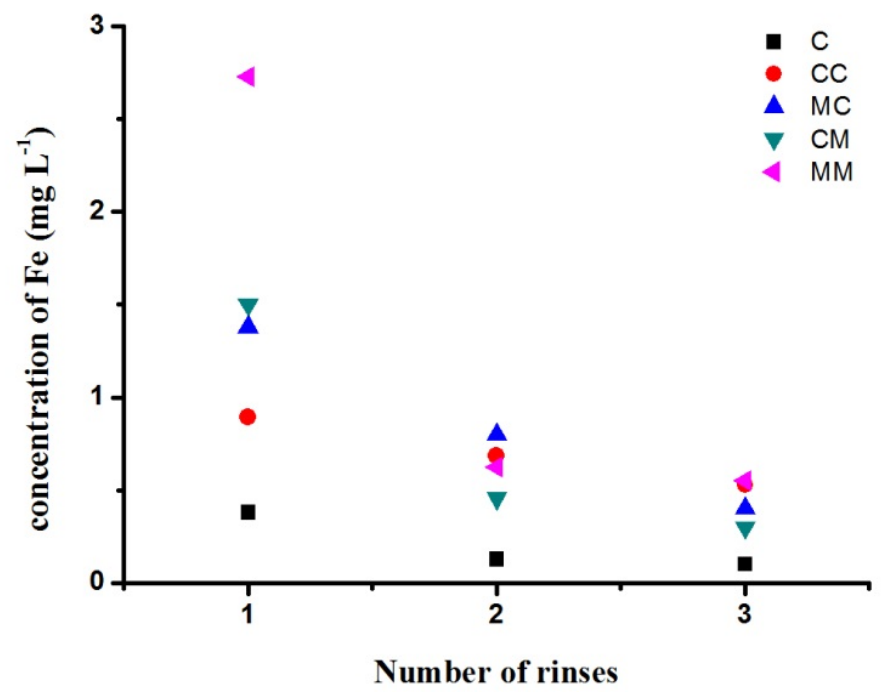

Figure 1. Decreasing of $\mathrm{Fe}$ concentration in the rinsing liquids Notations: C - no supplementation; CC - $5.70 \mathrm{mg} \mathrm{L}^{-1} \mathrm{Fe}, 2.90 \mathrm{mg} \mathrm{L}^{-1} \mathrm{Mn}$; $\mathrm{CM}$ - $5.70 \mathrm{mg} \mathrm{L}^{-1} \mathrm{Fe}, 6.25 \mathrm{mg} \mathrm{L}^{-1} \mathrm{Mn}$; MC - $15 \mathrm{mg} \mathrm{L}^{-1} \mathrm{Fe}, 2.90 \mathrm{mg} \mathrm{L}^{-1} \mathrm{Mn}$; $\mathrm{MM}-15 \mathrm{mg} \mathrm{L}^{-1} \mathrm{Fe}, 6.25 \mathrm{mg} \mathrm{L}^{-1} \mathrm{Mn}$. 


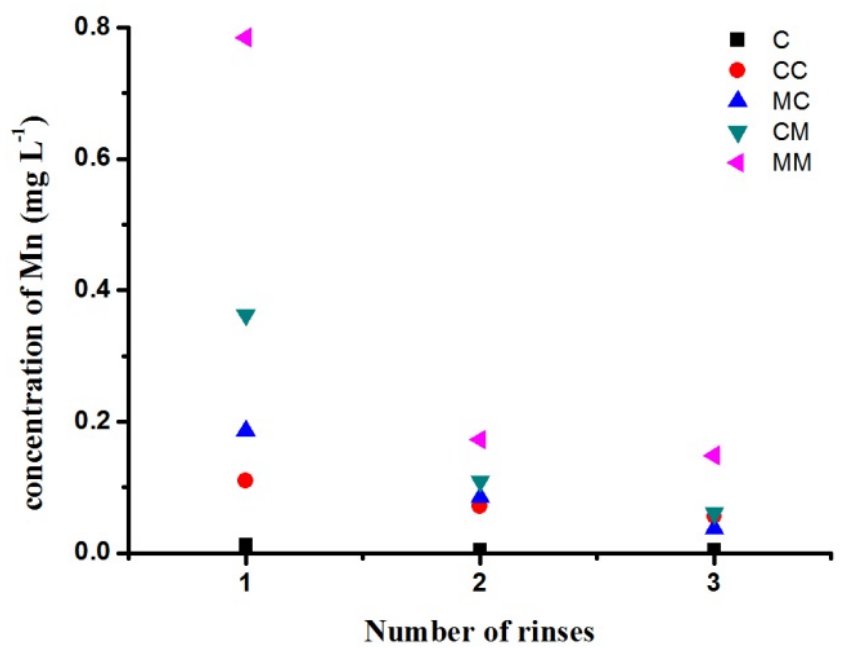

Figure 2. Decreasing of $\mathrm{Mn}$ concentration in the rinsing liquids Notations: C - no supplementation; CC $-5.70 \mathrm{mg} \mathrm{L}^{-1} \mathrm{Fe}, 2.90 \mathrm{mg} \mathrm{L}^{-1} \mathrm{Mn}$; $\mathrm{CM}-5.70 \mathrm{mg} \mathrm{L}^{-1} \mathrm{Fe}, 6.25 \mathrm{mg} \mathrm{L}^{-1} \mathrm{Mn} ; \mathrm{MC}^{-15} \mathrm{mg} \mathrm{L}^{-1} \mathrm{Fe}, 2.90 \mathrm{mg} \mathrm{L}^{-1} \mathrm{Mn}$; $\mathrm{MM}-15 \mathrm{mg} \mathrm{L}^{-1} \mathrm{Fe}, 6.25 \mathrm{mg} \mathrm{L}^{-1} \mathrm{Mn}$.

\section{Developement of sample preparation methods}

The applied method should carry the samples into solution by oxidizing the organic compounds without sample loss and contamination. In order to find the most suitable digestion two sample preparation methods (digestion in open system with conventional heating and in microwave assisted system) were compared for the $\mathrm{ERM}^{\circledR}-\mathrm{BB} 422$ sample. Elemental analytical results and recoveries are indicated in table 1.

No significant difference occurred between the two sample pre-treatment methods ( $p>0.05)$ neither for ICP-OES nor for MP-AES measurements, according to the statistical analysis. For the macro elements our results suggest that the more cost effective digestion in open system with conventional heating is suitable to eliminate the organic compounds and mobilize the measured elements present in the ERM ${ }^{\circledR}$-BB422 sample. The concentration values of $\mathrm{Zn}$ show a higher standard deviation in case of the MP-AES analysis, which may arise from the chosen wavelength $(213.857 \mathrm{~nm})$. The optical system of the MPAES instrument was not purged since the generator produces nitrogen gas enough only for the sample introduction (nebulizing), plasma supply and rinsing the pre-optics. In the UV range, further nitrogen supply is required from an additional gas cylinder to avoid the absorption of photons in air before reaching the detector, which would increase the sensitivity and decrease the standard 
deviation of parallel measurements in the lower range of emission lines, such as for $\mathrm{Zn}$. For the micro elements, further optimization of the digestion is necessary to improve the recovery results and decrease the standard deviation.

Table 1. The ICP-OES and MP-AES results of ERM ${ }^{\circledR}-B B 422$ (fish tissue) prepared by digestion in open system with conventional heating and

in a microwave assisted system $(\mathrm{N}=3)$

\begin{tabular}{|c|c|c|c|c|c|c|c|c|c|}
\hline \multirow{2}{*}{\multicolumn{2}{|c|}{ Elements }} & \multicolumn{4}{|c|}{ Found result+U } & \multicolumn{4}{|c|}{ Recovery \pm U (\%) } \\
\hline & & \multicolumn{2}{|c|}{ ICP-OES } & \multicolumn{2}{|c|}{ MP-AES } & \multicolumn{2}{|c|}{ ICP-OES } & \multicolumn{2}{|c|}{ MP-AES } \\
\hline$\left(\mathrm{g} \mathrm{kg}^{-1}\right)$ & $\begin{array}{l}\text { Certfied } \\
\text { value } \pm U\end{array}$ & $\begin{array}{c}\text { Open } \\
\text { syst. dig. }\end{array}$ & $\begin{array}{l}\text { Microwave } \\
\text { dig. }\end{array}$ & $\begin{array}{c}\text { Open } \\
\text { syst. dig. }\end{array}$ & $\begin{array}{l}\text { Microwave } \\
\text { dig. }\end{array}$ & $\begin{array}{c}\text { Open } \\
\text { syst. dig. }\end{array}$ & $\begin{array}{l}\text { Microwav } \\
\text { e dig. }\end{array}$ & $\begin{array}{c}\text { Open } \\
\text { syst. dig. }\end{array}$ & $\begin{array}{l}\text { Microwave } \\
\text { dig. }\end{array}$ \\
\hline $\mathrm{Ca}$ & $0.342^{*}$ & $0.327 \pm 0.026$ & $0.329 \pm 0.015$ & $0.335 \pm 0.033$ & $0.320 \pm 0.002$ & $96 \pm 8$ & $96 \pm 4$ & $98 \pm 9$ & $94 \pm 1$ \\
\hline Mg & $1.37^{*}$ & $1.45 \pm 0.05$ & $1.42 \pm 0.04$ & $1.37 \pm 0.01$ & $1.37 \pm 0.02$ & $106 \pm 4$ & $104 \pm 3$ & $100 \pm 1$ & $100 \pm 1$ \\
\hline $\mathrm{Na}$ & $2.80^{*}$ & $2.75 \pm 0.1$ & $2.79 \pm 0.15$ & $2.58 \pm 0.04$ & $2.59 \pm 0.01$ & $98 \pm 4$ & $99 \pm 5$ & $92 \pm 2$ & $93 \pm 1$ \\
\hline K & $21.4^{*}$ & $20.4 \pm 1$ & $21.3 \pm 1.3$ & $18.2 \pm 0.2$ & $18.6 \pm 0.2$ & $95 \pm 5$ & $99 \pm 6$ & $85 \pm 1$ & $87 \pm 1$ \\
\hline \multicolumn{10}{|l|}{$\left(\mathrm{mg} \mathrm{kg}^{-1}\right)$} \\
\hline $\mathrm{Cu}$ & $1.67 \pm 0.16$ & $1.65 \pm 0.04$ & $1.45 \pm 0.06$ & $1.75 \pm 0.15$ & $1.46 \pm 0.11$ & $99 \pm 3$ & $87 \pm 3$ & $105 \pm 9$ & $88 \pm 4$ \\
\hline $\mathrm{Fe}$ & $9.4 \pm 1.4$ & $8.1 \pm 0.4$ & $8.2 \pm 0.4$ & $10.3 \pm 0.3$ & $7.7 \pm 0.5$ & $87 \pm 4$ & $88 \pm 9$ & $109 \pm 3$ & $83 \pm 5$ \\
\hline Mn & $0.368 \pm 0.028$ & $0.361 \pm 0.029$ & $0.306 \pm 0.011$ & $0.427 \pm 0.012$ & $0.344 \pm 0.023$ & $98 \pm 8$ & $83 \pm 3$ & $116 \pm 3$ & $94 \pm 6$ \\
\hline $\mathrm{Zn}$ & $16.0 \pm 1.1$ & $13.9 \pm 0.5$ & $12.0 \pm 0.4$ & $14.1 \pm 1.6$ & $15.0 \pm 1.2$ & $87 \pm 3$ & $76 \pm 2$ & $88 \pm 10$ & $94 \pm 8$ \\
\hline
\end{tabular}

${ }^{*}$ Concentration values for macro elements are given without uncertainty in the certification document of $\mathrm{ERM}^{\circledR}$-BB422

The measurement results gained by MP-AES and ICP-OES were both compared to the expected data provided in the certificate document of the $\mathrm{ERM}^{\circledR}-\mathrm{BB} 422$ sample. Although the applied statistical analysis proved no significant difference, the results of micro elements show higher percentage difference in case of $\mathrm{Fe}$ and $\mathrm{Zn}$ for the ICP-OES analysis. For these elements the measuring parameters of the ICP-OES method should be further optimize, yet it is clearly seen, that the MP-AES technique is appropriate for the elemental analysis of biotic indicators of aquatic ecosystems, such as fish tissue.

Since MP-AES instrument has recently appeared commercially and only a few literature data is available discussing its applications so far [15$16]$, the method must be verified prior to the planned model experiments. According to our results a good agreement was found between the two techniques: with ICP-OES the digestion in open system with conventional heating gave a recovery of $96 \%$ as the average of the measured elements and $92 \%$ with microwave digestion. The same values are $99 \%$ and $92 \%$ with MPAES, respectively. These results indicate that despite the lower temperature of the nitrogen supplied microwave plasma, fish tissue samples can be analyzed 
with a similar precision to that of the ICP-OES. It suggests that with the applied initial sample masses, the more cost-effective MP-AES can be used for the elemental determination of biotic indicator organisms after the appropriate sample pre-treatment. The standard deviation is higher for the $\mathrm{Zn}$ values than for the other elements - additional nitrogen supply from a gas cylinder by an external gas box would decrease it significantly.

\section{CONCLUSIONS}

In this paper the development of analytical methods are described for the elemental analysis of biotic indicators applied in model experiments of toxicity studies. It was found that rinsing the zooplankton organisms after rearing in contaminated media is important prior to the sample preparation process to decrease the error of the elemental analytical results. The rinsing should occur three times with $2 \mathrm{ml}$ per grams (wet weight Artemia) of solution. It is further concluded that the digestion in open system with conventional heating is suitable for the sample pre-treatment of indicator organisms as well as the more cost-effective microwave plasma atomic emission spectrometer can be applied successfully for the quantitative determination of macro and micro elements. With ICP-OES the digestion in open system with conventional heating gave a recovery of $96 \%$ of $E M^{\circledR}-B B 422$ (fish tissue) as the average of the measured elements and $92 \%$ with microwave digestion. With MP-AES $99 \%$ and $92 \%$ were gained, respectively. The sensitivity of the MP-AES method can be increased for elements that have lines in the lower wavelengths of the emission spectra with additional nitrogen purge.

\section{EXPERIMENTAL SECTION}

\section{Enrichment and preparation of zooplankton organisms}

The examined zooplankton organisms (Artemia sp., Sera, Germany) were reared and enriched under laboratory conditions. During the experiment we have developed a model system, which ensures the optimal conditions to raise and breed the organisms. The brine shrimps were hatched in $1.5 \mathrm{~L}$ plastic containers, with the density of 4 grams egg per $\mathrm{L}$. The vessels were filled up with tap water aerated for $24 \mathrm{~h}$ and $20 \mathrm{~g} \mathrm{~L}^{-1}$ salt concentration was set. The temperature of the water was $27^{\circ} \mathrm{C}$ and 2000 lux illumination was adjusted by table lamps. After $24 \mathrm{~h}$ the newly hatched nauplii were separated from the shells and then collected by plankton net (mesh size of $150 \mu \mathrm{m}$ ). 
A series of preliminary experiments were set to choose the right concentrations of the applied elements ( $\mathrm{Fe}$ and $\mathrm{Mn}$ ) used for the enrichment period. In a previous study in a joint research we found oxbows of the second largest Hungarian river (Tisza) to be contaminated with Fe and Mn [17-19]. Ten times of these levels were taken in our experiments since the originally found concentrations proved to be too low for the zooplankton to accumulate.

The applied concentrations were the followings:

- $\mathrm{CC}$ (Fe: $5.70 \mathrm{mg} \mathrm{L}^{-1}, \mathrm{Mn}: 2.90 \mathrm{mg} \mathrm{L}^{-1}$ ),

- $\mathrm{CM}$ (Fe: $\left.5.70 \mathrm{mg} \mathrm{L}^{-1}, \mathrm{Mn}: 6.25 \mathrm{mg} \mathrm{L}^{-1}\right)$,

- $\mathrm{MC}$ (Fe: $\left.15 \mathrm{mg} \mathrm{L}^{-1}, \mathrm{Mn}: 2.90 \mathrm{mg} \mathrm{L}^{-1}\right)$,

- $\mathrm{MM}$ (Fe: $\left.15 \mathrm{mg} \mathrm{L}^{-1}, \mathrm{Mn}: 6.25 \mathrm{mg} \mathrm{L}^{-1}\right)$,

- C (control, no supplementation).

The solutions of $\mathrm{FeCl}_{3}$ and $\mathrm{MnCl}_{2}$ (SPEKTRUM 3D) were used to adjust the above mentioned concentrations in the model media. Separated newly hatched Artemia were placed and reared in the model solutions for 24 hours with continuous light and aeration. Each treatment was set in five replicates. After the enrichment period brine shrimps were filtered and rinsed with ultrapure water in three rounds to investigate the effect of rinsing on the level of enriched elements. Rinsing solutions were collected in polypropylene centrifuge tubes.

\section{Development of sample preparation methods}

European reference material (ERM ${ }^{\circledR}-\mathrm{BB} 422$, Fish Muscle) was used to test the sample preparation and elemental analytical methods. The ERM ${ }^{{ }_{-}}$ BB422 is certified for both micro and macro elements. The exact amount of two different initial masses $(0.2 \mathrm{~g}$ and $0.5 \mathrm{~g})$ were measured of the reference material on analytical balance (Precisa 40SM-200A), as well as two different sample preparation methods were compared. During the digestion in open system with conventional heating, samples were weighted into glass beakers and digested on an electric hot plate with $6.0 \mathrm{ml} 65 \%(\mathrm{~m} / \mathrm{m})$ nitric acid (reagent grade, Merck) and $1.0 \mathrm{ml} 30 \%(\mathrm{~m} / \mathrm{m}$ ) hydrogen peroxide (reagent grade, Merck) at $80^{\circ} \mathrm{C}$ for 4 hours [20]. After digestion, samples were diluted with $1 \%(\mathrm{v} / \mathrm{v})$ nitric acid (reagent grade, Merck and Milli-Q water) to a final volume of $10 \mathrm{ml}$. During the microwave assisted sample preparation method the samples were measured into closed Teflon containers and were digested with $4.0 \mathrm{ml} 65 \%(\mathrm{~m} / \mathrm{m})$ nitric acid (reagent grade, Merck) and $1.0 \mathrm{ml} \mathrm{30 \%}$ 
$(\mathrm{m} / \mathrm{m})$ hydrogen peroxide (reagent grade, Merck). After digestion, samples were diluted with $1 \%(\mathrm{v} / \mathrm{v})$ nitric acid (reagent grade, Merck and Milli-Q water) to a final volume of $10 \mathrm{ml}$ (Milestone, EthosUp).

\section{Elemental analysis}

Elemental concentration was determined from both rinsing solution applied for Artemia (Fe and Mn) and ERM ${ }^{\circledR}$-BB422 samples ( $\mathrm{Ca}, \mathrm{Mg}, \mathrm{Na}, \mathrm{K}$, $\mathrm{Cu}, \mathrm{Fe}, \mathrm{Mn}$, and $\mathrm{Zn}$ ) by microwave plasma atomic emission spectrometer (Agilent MP-AES 4200) as well as inductively coupled plasma optical emission spectrometer (Agilent Technologies ICP-OES SVDV 5100). Auto sampler (Agilent SPS3), Meinhard ${ }^{\circledR}$ type nebulizer and double pass spray chamber were used. We applied a five-point calibration procedure prepared from multielement standard solution (Merck ICP IV). For the method development each element was measured on at least 3 of the most intensive wavelengths; the shape of the gained spectra, the fitting of the calibration curve and the signal/background ratio was carefully investigated to choose the most appropriate wavelengths for further measurements. These were: $\mathrm{Ca}(315.887$ $\mathrm{nm}), \mathrm{Mg}(279.552 \mathrm{~nm}), \mathrm{Na}(589.592 \mathrm{~nm}), \mathrm{K}(766.491 \mathrm{~nm}), \mathrm{Cu}(324.754 \mathrm{~nm})$, $\mathrm{Fe}(234.350 \mathrm{~nm}), \mathrm{Mn}(257.610 \mathrm{~nm}), \mathrm{Zn}(202.548 \mathrm{~nm})$ for the ICP-OES measurements, and Ca (445.478 nm), Mg (383.829 nm), Na (589.592 nm), K (769.897 nm), Cu (324.754 nm), Fe (371.993 nm), Mn (403.076 nm) and Zn $(213.857 \mathrm{~nm})$ for the MP-AES measurements.

\section{Statistical analysis}

The two digestion methods (digestion in open system with conventional heating and in microwave assisted system) as well as the two techniques applied for the elemental analysis (MP-AES and ICP-OES) for the ERM ${ }^{\circledR}$ BB422 samples were compared by two way ANOVA (multivariate). The homogeneity was tested by Levene's test, while the significant differences were evaluated by Tukey's multiple comparison test. The calculations were conducted in SPSS software package (SPSS Statistics IBM 22) [11].

\section{ACKNOWLEDGMENTS}

We acknowledge the Agilent Technologies, the Milestone Srl. and the NovoLab Ltd. (Hungary) for providing the MP-AES 4200, the ICP-OES 5100 and the EthosUp. The research was supported by the EU and co-financed by the European Regional Development Fund under the project GINOP-2.3.2-15-2016-00008. Petra Herman was supported through the ÚNKP-16-2-I New National Excellence Program of the Ministry of Human Capacities. 


\section{REFERENCES}

1. S.N. Gajbhiye, R. Hirota, Journal of the Indian Fisheries Association, 1990, 20, 43.

2. A. Gupta, D.K. Rai, R.S. Pandey, B. Sharma, Environmental Monitoring and Assessment, 2009, 157, 449.

3. D.G. Sfakianakis, E. Renieri, M. Kentouri, A.M. Tsatsakis, Environmental Research, 2014, 137, 246.

4. S. Islam, K. Ahmed, M. Raknuzzaman, H. Al-Mamun, M.K. Islam, Ecological Indicators, 2014, 48, 282.

5. H. Lin, T. Sun, S. Xue, X. Jiang, Science of The Total Environment, 2016, 541, 435.

6. T. Watanabe, V. Kiron, S. Satoh, Aquaculture, 1997, 151, 185.

7. R.-J. Qu, X.H. Wang, M.B. Feng, Y. Li, H. X. Liu, L.-S. Wang, Z.Y. Wang, Ecotoxicology and Environmental Safety, 2013, 95, 83.

8. R. Sarabia, A. Torreblanca, J.J. Del Ramo, J. Díaz-Mayans, Comparative Biochemistry and Physiology Part A: Molecular \& Integrative Physiology, 1997, 120, 93.

9. C. Claus, F. Benijts, G. Vandeputte, W. Gardner, Journal of experimental Marine Biology and Ecology, 1979, 36, 171.

10. K. S. Subramanian, Spectrochimica acta, 1995, B51, 291-319.

11. M. Fehér, E. Baranyai, E. Simon, P. Bársony, I. Szücs, J. Posta, L. Stündl, Aquaculture, 2013, 414-415, 92.

12. P. Lo Nostro, B.W. Ninham, E. Carretti, L. Dei, P. Baglioni, Chemosphere, 2015, 135, 335.

13. V.T. Nguyen, S. Satoh, Y. Haga, H. Fushimi, T. Kotani, Aquaculture, 2008, 285, 184.

14. S. Matsumoto, S. Satoh, T. Kotani, H. Fushimi, Aquaculture, 2009, 286, 113.

15. C.T. Kamala, V. Balaram, V. Dharmendra, M. Satyanarayanan, K.S.V. Subramanyam, A. Krishnaiah, Environmental Monitoring and Assessment, 2014, 186, 7097.

16. W. Li., P. Simmons, D. Shrader, T.J. Herrman, S.Y. Dai, Talanta, 2013, 112, 43.

17. Z. Balogh, S. Harangi, J.T. Kundrát, I. Gyulai, B. Tóthmérész, E. Simon, Water, Air, \& Soil Pollution, 2016, 227.

18. J.T. Kundrát, I. Gyulai, E. Baranyai, K. Hubay, S. Harangi, Zs. Balogh, M. Braun, E. Simon, Hidrológiai Közlöny, 2014, 5-6, 53.

19. G. Lakatos, Toxicology Letters, 2003, 140-141, 333.

20. S. Harangi, E. Baranyai, M. Fehér, Cs.N. Tóth, P. Herman, L. Stündl, I. Fábián, B. Tóthmérész, E. Simon, Biological Trace Element Research, 2016. 